\title{
PARADIGMA DALAM ILMU ARKEOLOGI
}

\author{
Sondang M. Siregar \\ Balai Arkeologi Sumatera Selatan \\ sondangmartini70@gmail.com
}

\begin{abstract}
ABSTRAK
Arkeologi merupakan ilmu yang mempelajari masa lampau melalui benda yang ditinggalkannya. Pada mulanya muncul dari kegemaran orang mengumpulkan harta karun selanjutnya berkembang dengan rasa ingin tahu yang besar mengenai masa lampau. Kajian arkeologi tidak dapat berdiri sendiri karena memerlukan ilmu bantu di dalam penelitian arkeologi yang bertujuan menyusun sejarah kebudayaan, memahami perilaku manusia dan mengetahui proses perubahan kebudayaan. Maka penelitian dianggap berhasil apabila semakin banyak para ahli dalam berbagai disiplin ilmu terlibat dalam penelitian arkeologi.
\end{abstract}

\section{Kata Kunci: paradigma, ilmu, arkeologi}

\section{ABSTRACT}

Archeology is the study of the past through the objects it left behind. In the beginning, arises from the passion of people collecting treasure and then develop with great curiosity about the past. Archeological studies cannot stand alone because they require knowledge in archeological research aimed at compiling cultural history, understanding human behavior, and knowing the process of cultural change. Then the research is considered successful if more and more experts in various disciplines are involved in archeological research.

\section{Keywords: paradigm, science, archeology}

\section{PENDAHULUAN}

Arkeologi berasal dari kata archaeos (purbakala) dan logos (ilmu) yang artinya ilmu yang mempelajari masa lalu melalui benda-benda yang ditinggalkan.
Arkeologi muncul dari hobi atau kegemaran mengoleksi bendabenda masa lalu atau barangbarang antik dari masa Yunani, Romawi kuna. Pada masa itu terjadi perburuan barang-barang antik 
sehingga banyak kubur-kubur dibongkar, piramida-piramida dibom, dirusak atau dibom untuk diambil patung, perhiasan dan lainlain kemudian diperdagangkan pada pasar lelang dunia.

Kegemaran mengoleksi barang antik menyebabkan pasar barang antik dunia menjadi ramai dikunjungi orang pada abad ke-15 Masehi. Orang-orang Eropa mengoleksi barang-barang sebagai gengsi atau menaikkan derajat apalagi mengoleksi kesusastraan Yunani. Selanjutnya Bangsa Eropa tidak hanya sekedar mengoleksi kesusastraan Yunani namun juga mempelajari dipelajari Sejarah Yunani. Hal ini akhirnya mendorong minat dan kecenderungan orang untuk mempelajari ilmu pengetahuan di Italia khususnya di pusat perdagangan Venesia dan Genoa. Para pedagang Genoa dan Venesia mengambil kesempatan pergi ke negara-negara Eropa dan bukan Eropa dan pulangnya membawa benda dan kisah dari negaranegara yang telah dikunjungi.
Bangsa Eropa memiliki rasa ingin tahu yang tinggi dan tertarik mempelajari Renaisans, filsafat dan matematika, tertarik mempelajari tentang lingkungan termasuk dan lingkungan di luar bangsa Eropa dan semakin menyadari bahwa banyak kebudayaan lain di dunia (Djaya, 2012).

\section{HASIL DAN PEMBAHASAN}

\section{Perkembangan Ilmu Arkeologi}

Pada tahun 1492 sampai dengan tahun 1840, lahir konsep perbedaan bentuk kebudayaan, tidak hanya disebabkan oleh perbedaan waktu tetapi perbedaan ruang (geografik). Selanjutnya orang mengenal konsep 3 zaman yang teorinya dicetuskan oleh Thomson dari Denmark. Teori tersebut adalah menyebutkan bahwa zaman dahulu manusia terlah mengenal teknologi yang disebut 3 zaman terdiri dari zaman batu (yang tetua), zaman perunggu, dan zaman besi. Konsep 3 zaman memberikan arti bahwa masa lalu telah memiliki teknologi pembuatan alat-alat kerja dari manusia. Pada masa itu tercipta 
Hukum Worsae yaitu benda-benda yang terkubur bersama dalam 1 kubur atau 1 area diasumsikan sebagai benda-benda yang digunakan pada waktu yang sama karena itu pertanggalannya sama (Mundarjito, 2007)

Bangsa Eropa masih mengagumi filsafat Yunani sampai akhir abad ke-17 Masehi. Bahkan berkembang minat untuk mempelajari budaya bangsa lain dan mengumpulkan barang ke museum. Museum dikelola orangorang terpelajar dan secara berkala berdiskusi tentang barang-barang yang disimpan di museum dan selalu menghubungkan dengan cerita dan kisah kesusastraan Yunani dan Romawi. Orang Eropa mulai menyusun cerita masa lampau dari kesusastraan Yunani dan Romawi, walaupun dengan uraian yang terbatas, bahkan orang Eropa menggunakan sumber kitab Injil. Selain itu orang Eropa berusaha mencari pengetahuan tentang bangsanya sendiri pada masa itu. Rasa ingin tahu mendorong bangsa Eropa pergi ke luar negeri untuk mencari barangbarang antik dan mempelajari kisah dari barang-barang antik tersebut dan dikarenakan sumber pengetahuan bangsa Eropa sangat terbatas maka kesimpulannya mirip dongeng. Kesusastraan Yunani dan Romawi memberikan catatan singkat tentang masa lalu tetapi sangat singkat dan tersebar dari berbagai sumber, namun sumber-sumber banyak diabaikan oleh bangsa Eropa . (Munandar, 2011)

Pada abad ke-18 Masehi muncullah kesadaran bahwa kebudayaan muncul dari berbagai tahap dan munculnya ilmu-ilmu lain untuk membantu pengertian tentang masa lalu. Arkeologi muncul di beberapa negara Eropa dengan adanya berbagai temuan seperti fosil, gigi halilintar (beliung persegi), tulang-tulang namun dengan belum ditemukannya metode menghitung umur lapisan bumi. Umur lapisan tanah baru diketahui setelah muncul ilmu geologi modern. 
Pada tahun 1914 sampai dengan 1940 kemudian berkembang Teori Deposisi Stratigrafik (Lyell) dan teori Evolusi Biologis (Darwin) yang kemudian berkembang menjadi Teori Evolusi Budaya dan Teori Evolusi Masyarakat (Tylor dan Morgan). Pada masa ini yaitu masa klasifika historical, muncul apresiasi terhadap sains dengan rasionalismenya yaitu perkembangan industrialisasi di Eropa dan Amerika. Teori Lyell menyebutkan bahwa manusia telah ada di masa lalu yaitu pada zaman yang sudah tertimbun di dalam tanah dan membentuk lapisan tertentu, apabila lapisan tersebut dapat dihitung yaitu ketika manusia purba masih hidup dapat diketahui. Konsep-konsep yang muncul di Eropa memberikan makna yang sederhana dengan tujuan memberikan makna kulturhistoris kepada benda-benda arkeologi yang selanjutnya diolah dan dipelajari sehingga mendapatkan model yang bisa dipertanggungjawabkan oleh banyak orang (Colin, 1997)

Tahun 1940 sampai tahun 1960, kajian dimensi bentuk, ruang dan waktu mulai berkembang khususnya kajian jejak-jejak distribusi budaya. Selanjutnya setelah tahun 1960 semakin banyak data dan interpretasi arkeologi yang mempengaruhi sikap dari pada arkeolog dalam mengkaji upaya menghubungkan antara tujuan untuk memahami proses budaya dan merekonstruksi sejarah dari kebudayaan. Pada masa ini muncul paradigma New Archaeology yang memberi pengaruh perkembangan Historical Archaeology (Soekmono, 1973)

\section{Arkeologi Butuh IImu Bantu}

Selanjutnya orang melalui kebudayaan masa lalu melalui kajian sistematis atas data benda yang ditinggalkan manusia seperti penemuan, dokumentasi, analisis data interpretasi berupa situs, artefak, ekologi, fitur. Tujuan arkeologi beragam dan menjadi perdebatan dalam waktu yang lama, di antaranya disebut dengan 
paradigma arkeologi yaitu memiliki tujuan menyusun sejarah kebudayaan, memahami perilaku manusia dan mengetahui proses perubahan kebudayaan. Oleh karena ilmu arkeologi bertujuan memahami budaya manusia maka dikenal dengan menjadi ilmu humaniora. Maka ilmu arkeologi membutuhkan berbagai ilmu batu dalam pelaksanaan penelitian di antaranya sejarah, antropologi, geologi, geografi, arsitektur, paleoantropologi, bioantropologi, fisika, ilmu metalurgi dan filoenetika dari fosil tersebut, begitu juga pakar kimia yang mengkaji usia fosil

Arkeologi mempelajari budaya pada masa lalu yang baik yang berasal dari masa Prasejarah (sebelum mengenal tulisan) dari masa Protosejarah (masa transisi antara Prasejarah dan Sejarah) dan masa Sejarah (manusia sudah mengenal tulisan). Pada masa sekarang, arkeologi melakukan kajian budaya bendawi modern (modern material culture). Oleh karena arkeologi mempelajari benda-benda peninggalan masa lalu, maka arkeologi memerlukan kelestarian benda-benda sebagai sumber data arkeologi. Maka kemudian berkembang disiplin ilmu lain seperti ilmu pengelolaan sumber daya arkeologi (Archaeological

Resources

Management) atau dikenal dengan nama pengelolaan sumber daya budaya (Culture Resouces Management) (Mundarjito, 2007). Begitupula ilmu arkeologi berkembang karena kebutuhan mempublikasikan hasil-hasil penelitian baik melalu media cetak dan media elektronik sehingga publik (masyarakat) tahu perkembangan hasil penelitian yang dilakukan oleh para arkeolog, maka ilmu tersebut arkeologi publik (Public Archaeology). Ilmu arkeologi juga berkembang untuk mempelajari budaya masa lalu yang masih digunakan masyarakat sekarang seperti pembuatan alat terbuat bahan batu contohnya alat kapak (beliung persegi). Masyarakat Irian (suku Dani) masih membuat peralatan batu, 
merupakan kebudayaan dai masa Prasejarah, atau para pengunjung dari Desa Kebur (Lahat) membuat wadah-wadah terbuat dari bahan tanah liat seperti tempayan, kendi, periuk yang merupakan kebudayaan dari masa bercocok tanam (Prasejarah). Ilmu yang mempelajari benda-benda masa lalu (arkeologi) yang dipakai oleh masyarakat sekarang disebut etnoarkeologi.

\section{PENUTUP}

Ilmu arkeologi pada dasarnya tidak dapat berdiri sendiri, tetapi memerlukan ilmu lain dalam menganalisis temuan arkeologi. Penelitian-penelitian arkeologi yang memiliki anggaran besar, umumnya menyediakan anggaran untuk membayar honor para pakar ilmu lain yang terlibat dalam penelitian arkeologi. Sehingga umumnya tim penelitian arkeologi beranggotakan banyak orang yang berasal dari berbagai bidang ilmu. Semakin banyak para ahli dari luar bidang arkeologi terlibat dalam penelitian arkeologi khususnya membantu dalam menganalisis berbagai macam temuan arkeologi maka penelitian tersebut dianggap berhasil dan sering kali memperoleh kebaharuan dalam perkembangan ilmu arkeologi.

\section{DAFTAR PUSTAKA}

Djaya, Wahyudi. 2012. Sejarah Eropa : Dari Eropa Kuno hingga Eropa Modern: Yogyakarta: Ombak.

Koentjaraningrat, 2007. Sejarah Teori Antropologi I. Jakarta: Universitas Indonesia Press.

Munandar, Agus Aris, 2011.Sejarah Permuseuman di Indonesia. Jakarta: Direktorat Permuseuman Indonsia.

Mundarjito, 2007. Paradigma dalam Arkeologi Maritim. Wacana. Vol. 9 (1).

Renfrew, Colin and Bahn, Paul, 1997.Archaeology, Tehories, Methods and Practise. Thames and Hodson: London

Soekmono, R. 1973. Pengantar Sejarah Kebudayaan Indonesia I. Yogyakarta: Kanisius. 